U.S. Department of the Interior

U.S. Geological Survey

\title{
Volcano Hazards at Fuego and Acatenango, Guatemala
}

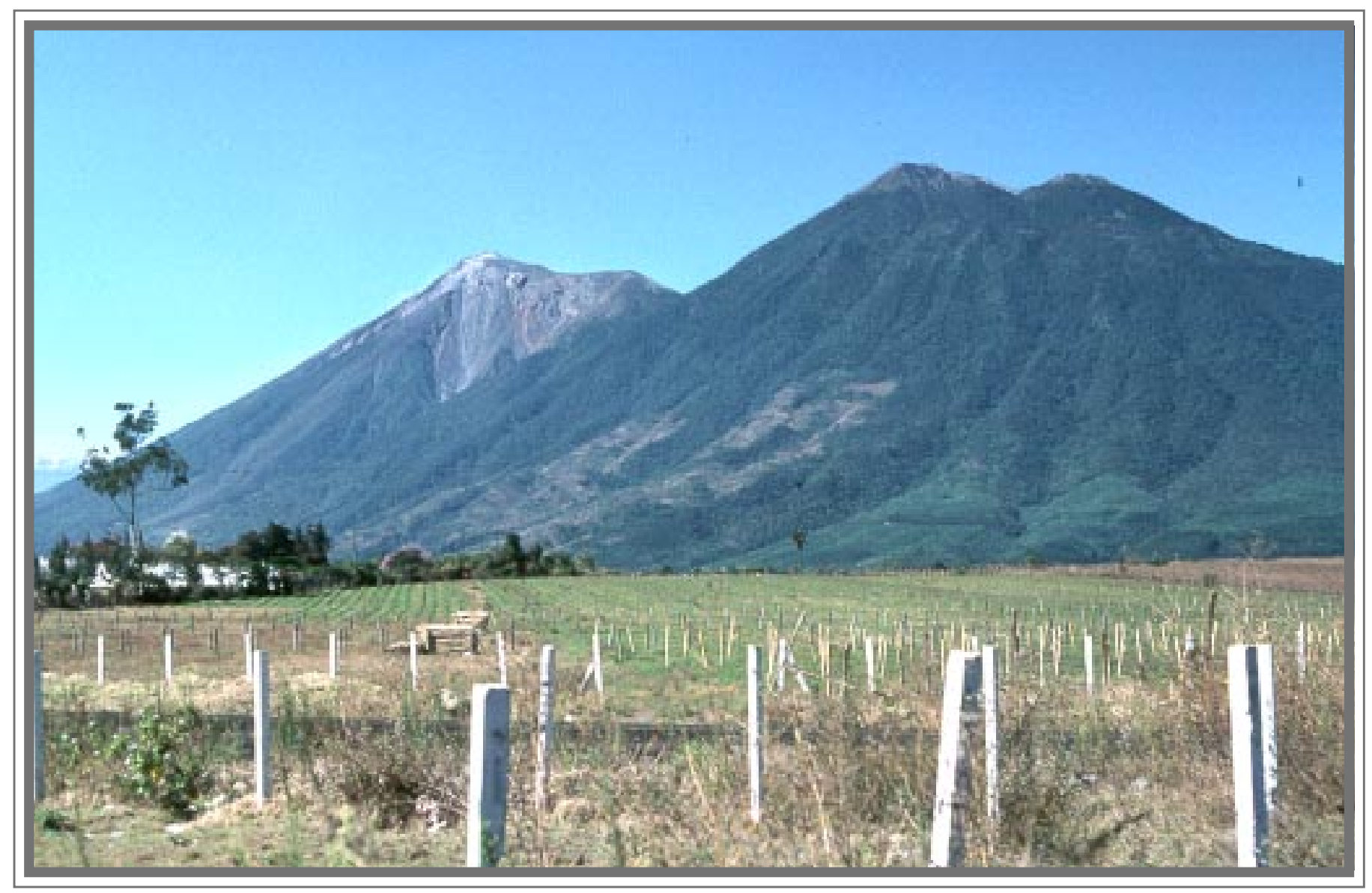

Open-File Report 01-431

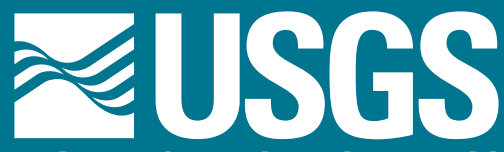




\section{Cover photograph}

Fuego and Acatenango volcanoes viewed from the east. Acatenango is to the right with Yepocapa to the far right and Pico Mayor next to it. Fuego is to the far left, and the bare bench just to the right is Meseta. (Photo by J.W. Vallance). 


\section{Volcano Hazards at Fuego and Acatenango, Guatemala}

By J.W. Vallance, S.P. Schilling, O. Matías, W.I. Rose, and M.M Howell

\section{U.S. GEOLOGICAL SURVEY}

Open-File Report 01-431 


\section{U.S. DEPARTMENT OF THE INTERIOR \\ Gale Norton, Secretary}

U.S. GEOLOGICAL SURVEY

Charles G. Groat, Director

This report is preliminary and has not been reviewed for conformity with U.S. Geological Survey editorial standards. Any use of trade, product, or firm names is for descriptive purposes only and does not imply endorsement by the U.S. Government.

For additional information write to:

Copies of this report can be purchased from:

\section{Scientist-in-Charge}

U.S. Geological Survey

1300 SE Cardinal Court, BIdg. 10

Vancouver, WA 98683

(360) $993-8900$

FAX: (360) 993-8980
U.S. Geological Survey

Information Services

P.0. Box 25286

Denver, CO 80225

(303) 202-4210 


\section{CONTENTS}

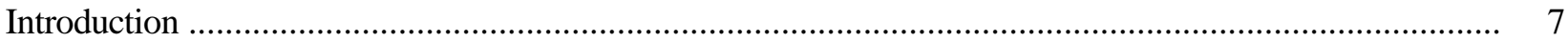

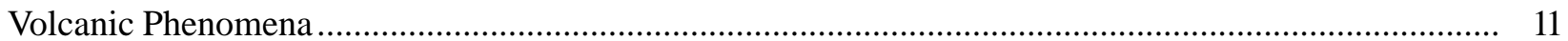

Hazardous phenomena at composite volcanoes ......................................................................... 11

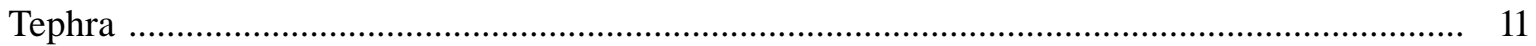

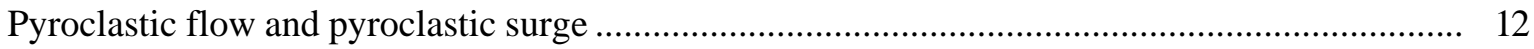

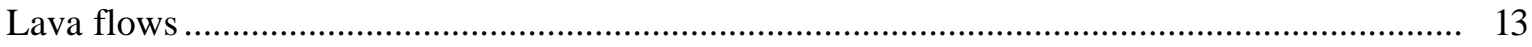

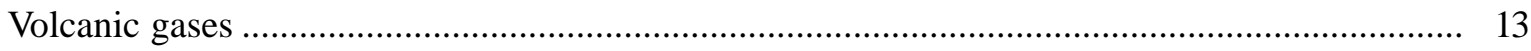

Debris avalanches, landslides, and lahars ....................................................................... 13

Past Events at Fuego and Acatenango Volcanoes ........................................................................ 14

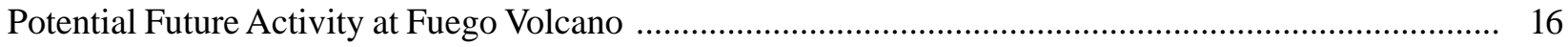

Potential Future Activity at Acatenango Volcano ........................................................................ 16

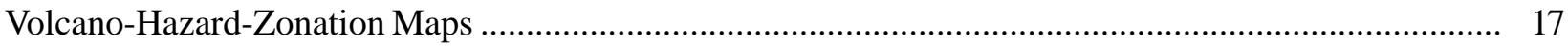

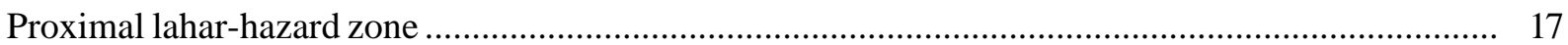

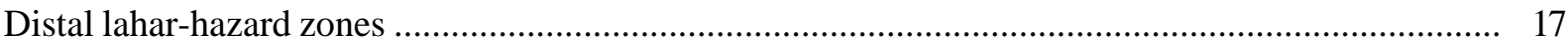

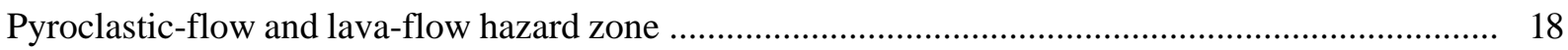

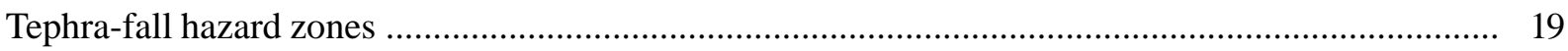

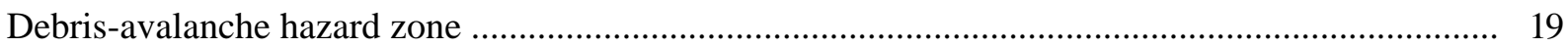

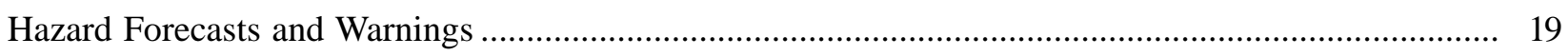

Protecting Communities and Citizens from Volcano-Related Hazards .............................................. 21

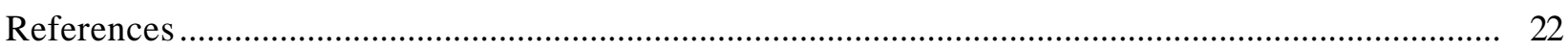

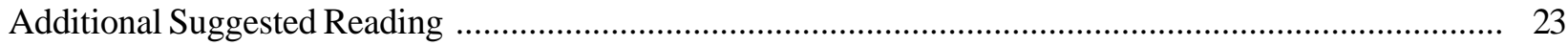

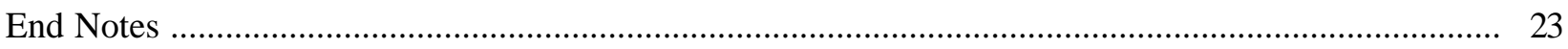

\section{PLATES [In pocket]}

1. Lahar hazards of Fuego volcano, Guatemala. Proximal and distal hazard zones from lahars at Fuego volcano.

2. Lahar hazards of Acatenango volcano, Guatemala. Proximal and distal hazard zones from lahars at Acatenango volcano.

3. Volcano hazards of Fuego volcano, Guatemala. Hazard zones that could be affected by lava flows, pyroclastic flows, and pyroclastic surges.

4. Volcano hazards of Acatenango volcano, Guatemala. Hazard zones that could be affected by lava flows, pyroclastic flows, and pyroclastic surges. 


\section{FIGURES}

1. Location of major cities and significant Quaternary volcanoes in Guatemala showing the location of Fuego and Acatenango volcanoes

2. Topographic map showing the major vents of the Fuego-Acatenango volcano complex ................. 8

3. Schematic illustration of the Fuego-Acatenango massif showing the 5 individual vents .................. 8

4. Historic activity of Fuego volcano ......................................................................................... 9

5. Composite section and summary of eruptive history of Acatenango volcano .............................. 10

6. Simplified sketch showing hazardous events associated with volcanoes like Fuego and Acatenango

7. Topographic map showing distribution of debris-avalanche deposits from the Fuego-Acatenango volcano complex and hazards from future debris avalanches

8. Topographic map showing distribution of pyroclastic flows (denoted glowing avalanches here) and tephra fall thicker than $20 \mathrm{~cm}$ from the 1974 eruption of Fuego volcano

9. Map showing population density and tephra-fall hazard zones of 20 centimeters at 15 kilometers distance, 10 centimeters at 25 kilometers distance, and 5 centimeters at 50 kilometers distance for the Fuego-Acatenango volcano complex

10. Map showing the probability of wind directions between 10,000 and 50,000 feet for Guatemala

\section{TABLE}

1. Population that could be affected by tephra falls like those of 1974 from Fuego 


\section{Volcano Hazards at Fuego and Acatenango, Guatemala}

\section{By J.W. Vallance, S.P. Schilling, O. Matías', W.I. Rose ${ }^{2}$, and M.M Howell}

\section{INTRODUCTION}

The Fuego-Acatenango massif comprises a string of five or more volcanic vents along a north-south trend that is perpendicular to that of the Central American arc in Guatemala (figure 1). From north to south known centers of volcanism are Ancient Acatenango, Yepocapa, Pico Mayor de Acatenango, Meseta, and Fuego (figures 2 and 3). Volcanism along the trend stretches back more than 200,000 years. Although many of the centers have been active contemporaneously, there is a general sequence of younger volcanism, from north to south along the trend.

This massive volcano complex towers more than 3500 meters (m) above the Pacific coastal plain to the south and $2000 \mathrm{~m}$ above the Guatemalan Highlands to the north. The volcano complex comprises remnants of multiple eruptive centers (figures 2 and 3), which periodically have collapsed to form huge debris avalanches. The largest of these avalanches extended more than

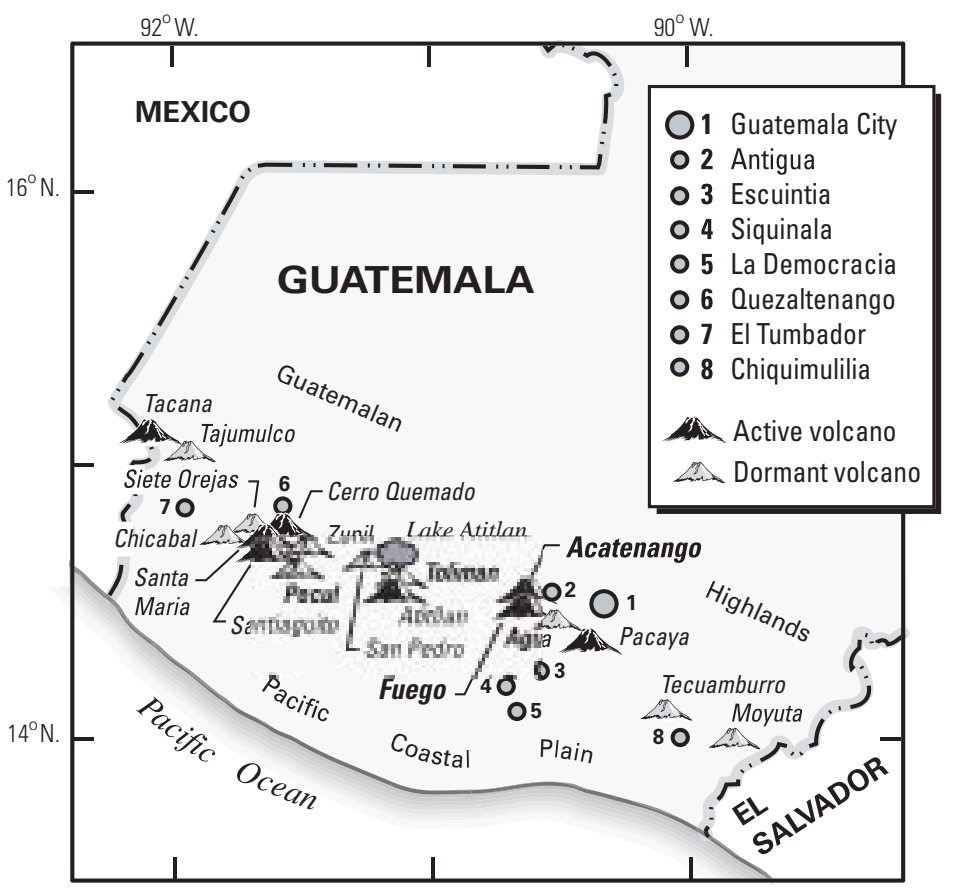

Figure 1. Location of major cities and significant Quaternary volcanoes in Guatemala showing the location of Fuego and Acatenango volcanoes. Circles indicate major cities, solid triangles indicate active volcanoes and open triangles indicate dormant volcanoes. Atitlán is a large silicic caldera.

\footnotetext{
${ }^{1}$ Instituto sismología, vocanología, meteorología, y hidrología (INSIVUMEH), Guatemala.

${ }^{2}$ Michigan Technological University, Houghton MI, 49931, USA
} 


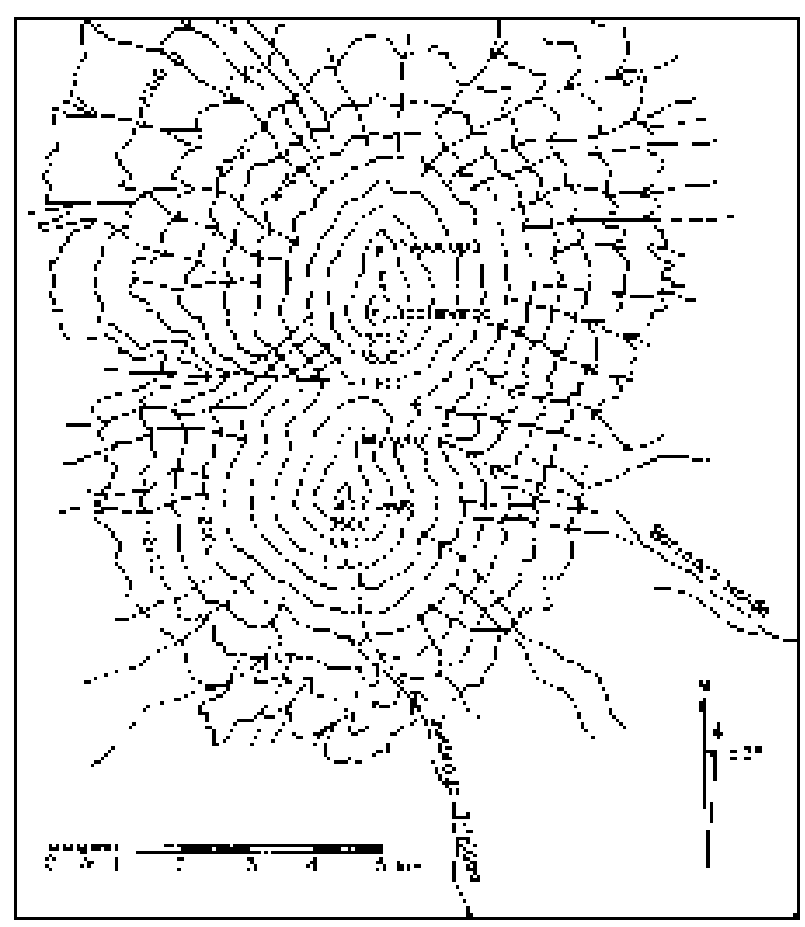

Figure 2 Topographic map showing the major vents of the Fuego-Acatenango volcano complex (adapted from Chesner and Rose, 1984)

50 kilometers $(\mathrm{km})$ from its source and covered more than $300 \mathrm{~km}^{2}$ [1](numerals in brackets refer to end notes in the report). The volcano has potential to produce huge debris avalanches that could inundate large areas of the Pacific coastal plain. In areas around the volcanoes and downslope toward the coastal plain, more than 100,000 people are potentially at risk from these and other flowage phenomena.

In historical time, Fuego has erupted more than 60 times (figure 4). It has spread volcanic ash to population centers such as Escuintla (population 75,000+) $20 \mathrm{~km}$ to the south, Antiqua (population 25,000) $15 \mathrm{~km}$ to the southwest and Guatemala City (population 2.2 million), the country's capital and largest city, $40 \mathrm{~km}$ to the southwest (figure 1). The volcano commonly produces plumes of fine ash up to $10 \mathrm{~km}$ high, lava flows, and hot pyroclastic flows. During periods of rain, volcaniclastic debris remobilizes to form volcanic debris flows (also commonly known as lahars). After periods of volcanism, channels are choked with sediment. As a result, floods spill onto adjacent interfluves, and periodically river channels change their course.

The only known historical eruptions of Acatenango volcano occurred in the $20^{\text {th }}$ century, between 1924 and 1927 from just north of the summit peak (Pico Mayor) and again in December 1972 from the saddle between Yepocapa and Pico Mayor (figure 2) [1]. These phreatic explosions generated ballistic bombs that fell near the summit craters and fine ash that fell up to $25 \mathrm{~km}$ away. In prehistoric time, Acatenango has erupted explosively to form widespread fall deposits, hot pyroclastic flows and lava flows. There have been numerous eruptions during the past 80,000 years from vents along the massif. The most recent explosive eruptions of Acatenango occurred 1900 years ago (Pico Mayor), 2300 years ago (Pico Mayor) and about 5000 years ago (Yepocapa) (figure 5). If such eruptions were to recur, many people and costly infrastructure would be at risk.

Volcanic eruptions are not the only events that present a risk to local communities. Another concern is a small- to moderate-sized landslides that could occur during periods of no volcanic activity. Landslides could be triggered on Acatenango and Fuego volcanoes by torrential rainstorms and earthquakes, and as they move down slope such landslides can transform into lahars that can inundate downstream areas beyond the edifice. Fuego demonstrates a more likely

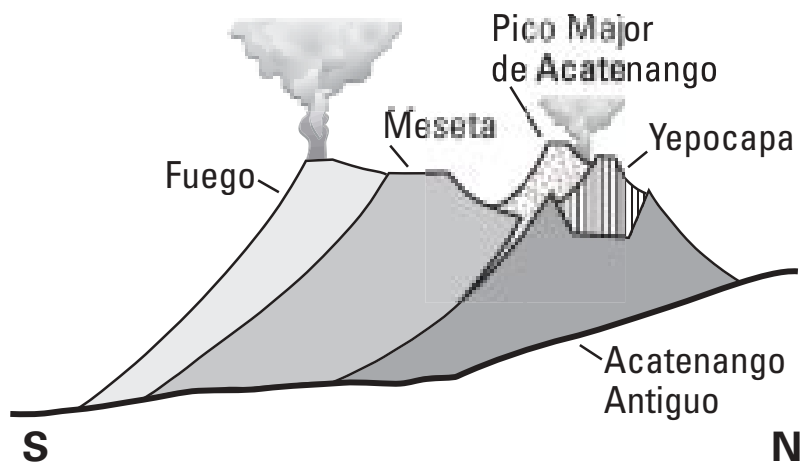

Figure 3. Schematic illustration of the FuegoAcatenango massif showing the 5 individual vents. (Adapted from Basset, 1996). Plumes indicate vents active in historic time. 
scenario in which torrential rains trigger debris flows by mobilizing fresh pyroclastic debris in the steep barrancas of the edifice. The rain-induced lahars that occurred after the modest eruptions of 1999 at Fuego show the destructive power of even small events. These debris flows destroyed newly constructed highway bridges in at least two places east of the volcano.
This report describes the kinds of hazardous events that occur at volcanoes in general and the kinds of hazardous geologic events that have occurred at Acatenango and Fuego in the past. The report also shows, in the accompanying volcano-hazards-zonation maps, which areas are likely to be at risk when hazardous events occur again.
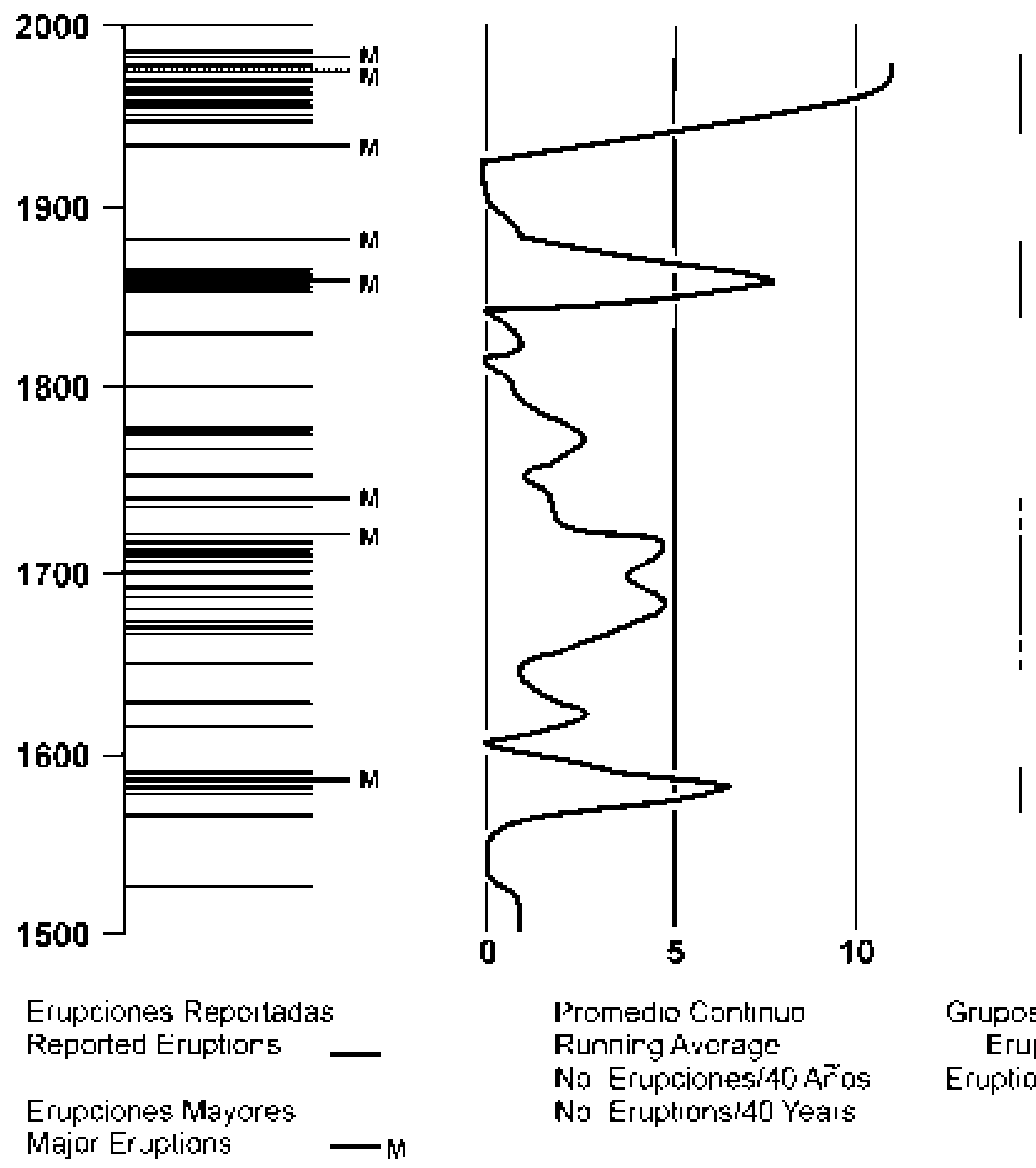

Promedio Goritinuo

Rபாாігg A.⿲eragn

No Ertptorisita Yeals
Grupos de ヒven:os

Eruptivos

Eruption Clusters

Figure 4. Historic activity of Fuego volcano. (Modified from Rose et al., 1978). 


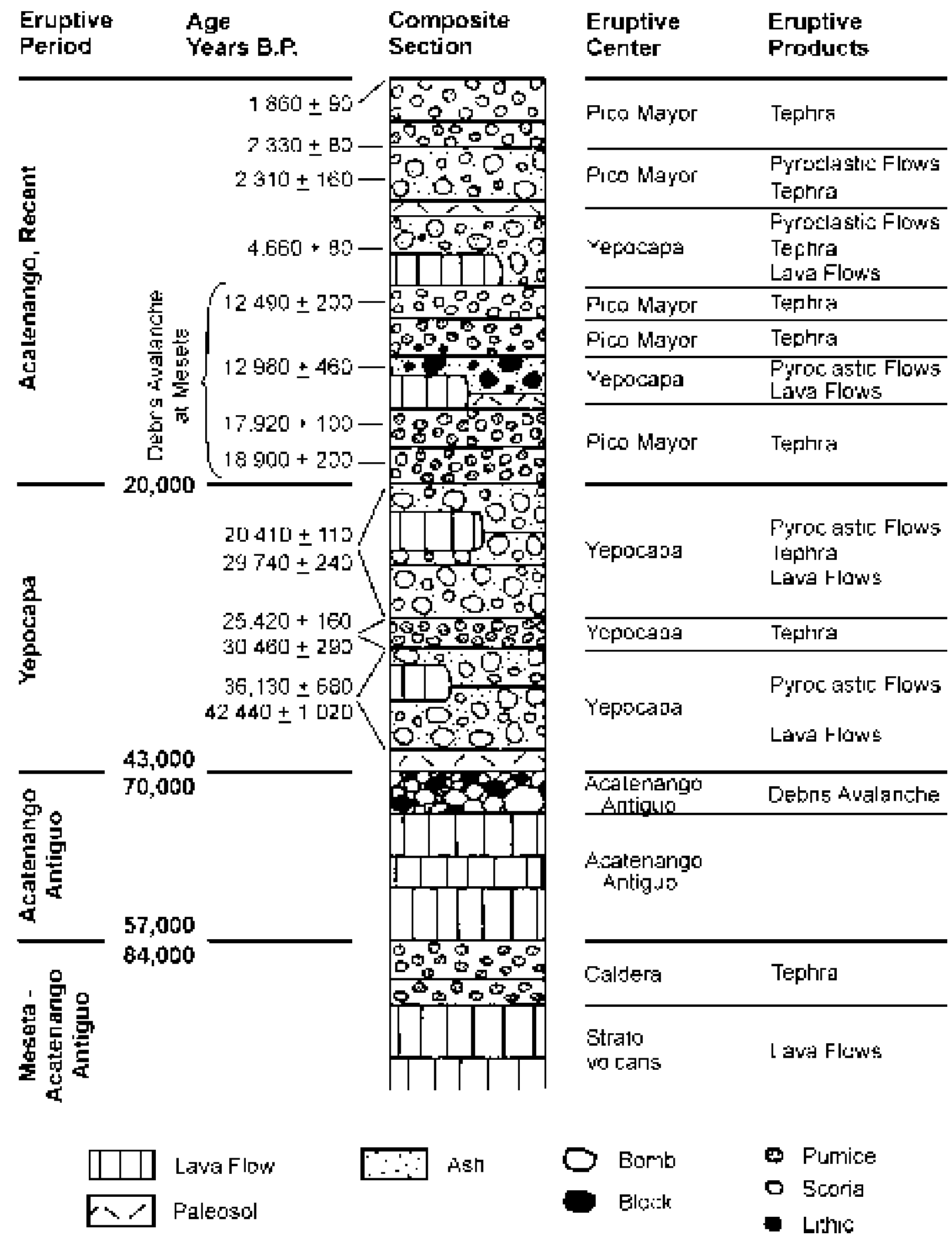

Figure 5. Composite section and summary of eruptive history of Acatenango volcano, based on Basset (1996). 


\section{VOLCANIC PHENOMENA}

Volcanoes pose a variety of geologic hazardsboth during eruptions and in the absence of eruptive activity (figure 6). Many of the hazardous events depicted in figure 6 have occurred at Fuego and Acatenango volcanoes in the past and will likely occur in the future. The eruption of molten rock, or magma, caused most of these events, but some, like some landslides and lahars, can occur without eruptive activity. The nature of activity depends in part on the size and type of volcano, the composition of the magma, and on interactions between magma and ground water.

The Fuego-Acatenango massif comprises a complex of five composite volcanoes along a north-south trend. Composite volcanoes erupt episodically. In historical time, small pyroclastic eruptions have occurred every few years at Fuego and relatively larger ones occur about every 30 years (figure 4). The older stratigraphic record documents several yet larger eruptions than these in the past 3000 years. Acatenango and the other cones in the chain have erupted much less frequently, but, on the basis of their geologic record can produce voluminous pyroclastic eruptions. Episodic volcanism along the massif extends more than 230,000 years into the past.

\section{Hazardous phenomena at composite volcanoes}

\section{Tephra}

As magma nears the surface of a volcano, it releases dissolved gases. Rapidly released gas fragments the solidifying magma into particles. If fragmenting particles exit the conduit at large velocities, they are dispersed high into the atmosphere. Volcanologists call such fragments, which range in size from microscopic ash to metersized blocks, tephra. Tephra falls from eruption plumes downwind and deposits broad lobes of ash away from the volcano. A tephra deposit's thickness and particle size generally decrease away from the vent, but a deposit can cover areas tens to hundreds of kilometers from the source. The largest tephra fragments, called ballistic bombs, fall to the ground within a few kilometers of the vent.

Tephra falls seldom threaten life directly, except within a few kilometers of a vent. The impact of large ballistic fragments can cause death or severe injury. Large projectiles may also be hot when they land and can start fires if they fall onto combustible material. Most injuries and fatalities from tephra falls occur when the tephra accumulations are thick, or are wet, and thus are heavy enough to collapse roofs of buildings and houses. Fine tephra suspended in the air can irritate eyes and lungs, especially among the elderly and infants.

Indirect effects of tephra falls can be perhaps more disruptive than the direct effects of tephra falls. Tephra plumes can create tens of minutes or more of darkness, even on sunny days, and tephra falls can reduce visibility. Engines can ingest fine ash that, in turn, clogs filters or increases wear. Tephra can short-circuit electric transformers and break power lines, especially if it is wet, sticky, and heavy. It can contaminate surface water, plug storm- and sanitary-sewer systems, and clog irrigation canals. Even thin tephra accumulations may ruin crops. Even small, dilute tephra clouds can damage jet aircraft that fly into them. Ash ingested by jet engines abrades them and melts within them causing engine malfunction and power loss.

In historical time, eruptions of Fuego volcano have repeatedly spread tephra blankets more than $100 \mathrm{~km}$ downwind and deposited thicknesses of 10 to 20 centimeters $(\mathrm{cm})$ to distances of between 15 and $25 \mathrm{~km}$ downwind [1]. During the eruption of 14 September 1971, in the town of Yepocapa, $10 \mathrm{~km}$ to the ENE of Fuego, tephra darkened skies caused panic among some residents, and ultimately collapsed roofs of some houses. Although many roofs collapsed, houses of residents who stayed behind and periodically swept their roofs experienced little damage. During the 1974 eruptions of Fuego, tephra plumes rose as high as $7 \mathrm{~km}$ above the volcano. These tephras, like others, chiefly comprised fine ash. Near source, however, tephra falls included numerous greaterthan-1-cm particles of basaltic pumice. 


\section{Pyroclastic flow and pyroclastic surge}

Sometimes the mixture of hot gases and volcanic rock particles produced by an explosive eruption is denser than air, and instead of rising above the vent to produce tephra, this dense mixture behaves like a fluid, stays close to the ground, and flows down slope as a pyroclastic flow. If the mixture contains large proportions of particles, then its density will tend to funnel it into topographically low areas, like barrancas and valleys. However, sufficiently voluminous flows or sequences of voluminous flows, especially on the slopes of the cone, may fill barrancas and sweep across fans in between them. Pyroclastic flows commonly generate dilute mixtures of hot ash and gas, called pyroclastic surges. These flows can

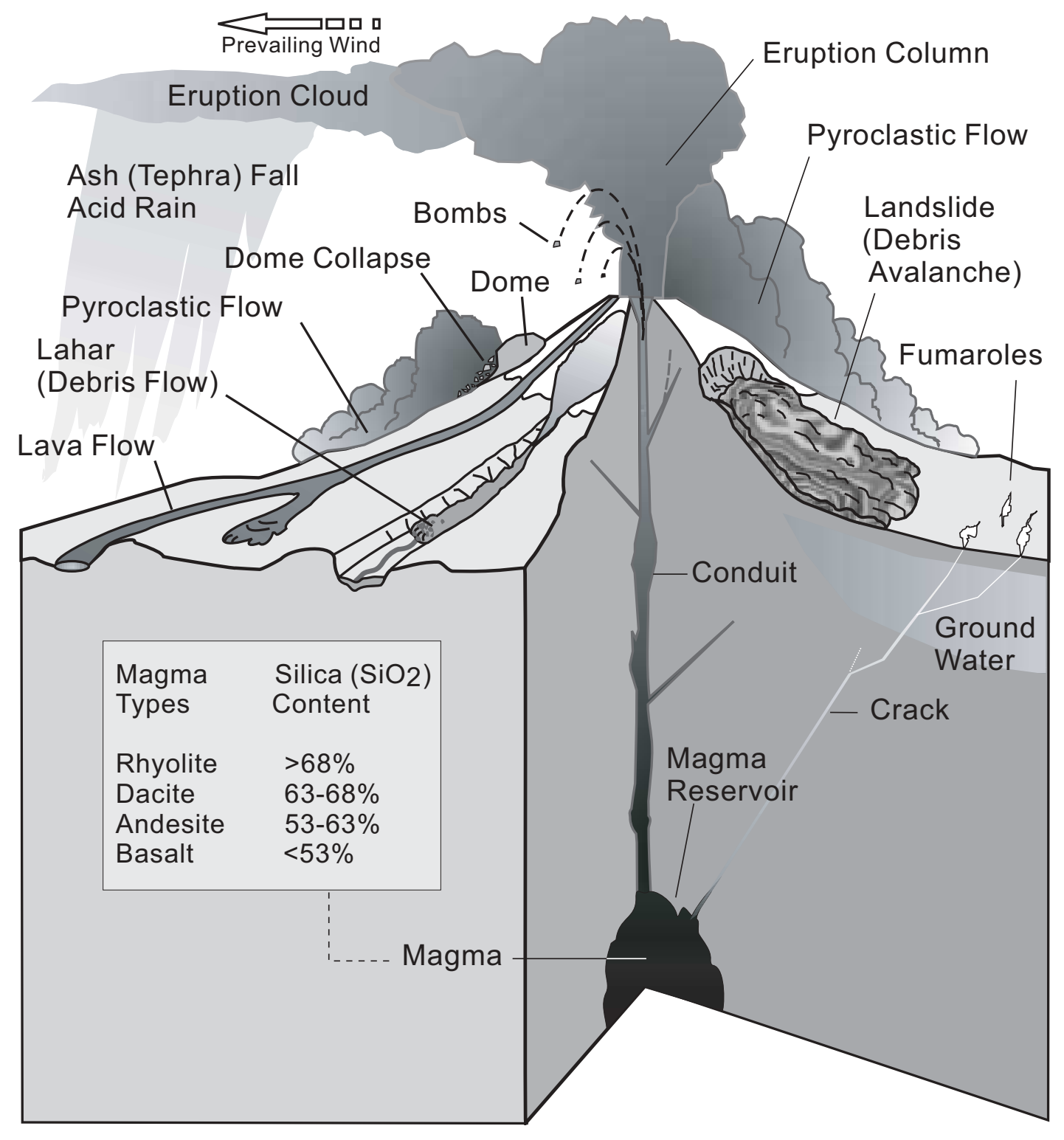

Figure 6. Simplified sketch showing hazardous events associated with volcanoes like Fuego and Acatenango. Events such as lahars and landslides (debris avalanches) can occur even when the volcano is not erupting. Inset box shows classification of magma types on the basis of silica content. Illustration by Bobbie Meyers, modified from USGS Fact Sheet 002-97. 
separate from the pyroclastic flow and move onto higher areas adjacent to or beyond the margins of pyroclastic flows.

Pyroclastic flows and surges move at speeds of 50 to $150 \mathrm{~km}$ per hour and people on foot cannot escape from them. Temperatures in pyroclastic flows and surges commonly are several hundred degrees Celsius or more. Pyroclastic flows commonly destroy all structures and kill all living things in their paths. Although pyroclastic surges may be somewhat less destructive, they can affect larger areas and be lethal. Pyroclastic surges often cause severe burns, trauma to the lungs, or suffocation.

Pyroclastic flows at Fuego are common during eruptions that occur at Fuego every few years. The most recent of these were in May 1999. Larger pyroclastic eruptions occur at about 30-year intervals as in 1974 and 1932. Judging by distribution of deposits and radiocarbon age determinations, even larger eruptions occurred about 900, 1200, and 3300 years ago. Pyroclastic eruptions have occurred at both Pico Mayor de Acatenango about 2300 years ago and Yepocapa 4700 years ago, and similar eruptions extend back to $c a 40,000$ years ago [1]. Pyroclastic flows at Fuego or Acatenanago generally have not moved more than $12 \mathrm{~km}$ from their sources.

\section{Lava flows}

If magma degasses enough before it reaches Earth's surface, it may erupt passively to form lava. Lava flows of the type that have formed at Acatenango and Fuego are blocky and reasonably slow moving. Such lava flows commonly move down slope as bouldery streams of rock a few to tens of meters thick and move at tens of meters per minute to a few tens of meters per hour. Although lava flows can be extremely destructive, they typically are not life threatening. People can walk out of the path of an advancing flow, but they should be aware that these flows are extremely unstable on the steep slopes of volcanoes like Fuego and could avalanche to form hot pyroclastic avalanches and flows from which there is little chance of escape.
Lava flows have originated at all the vents of the Fuego-Acatenango massif and have moved down all of its sides. Typically such flows have not moved more than about $10 \mathrm{~km}$ from source. In historical time, lava flows at Fuego have commonly broken up and formed hot avalanches or pyroclastic flows as they descended the steep east, south and west slopes of the volcano.

\section{Volcanic gases}

All magmas release gases both during and between eruptions. Volcanic gases include steam, carbon dioxide, sulfur dioxide, and small amounts of several other gases. Generally, volcanic gases dissipate rapidly downwind from the vent, but within a few kilometers of a vent they can be dangerous. Gases can injure eyes and lungs. In closed depressions, denser-than-air gases (like carbon dioxide) can accumulate and cause suffocation. The greatest hazards from volcanic gases at Fuego and Acatenango will be within the central summit craters.

\section{Debris avalanches, landslides, and lahars}

Slope failure of a volcano can generate a rapidly moving landslide called a debris avalanche. Magma intrusion and volcanigenic earthquakes can cause slope instability and deepseated failure like the one that occurred in 1980 at Mount St. Helens. In prehistoric time, at least two avalanches of this type have occurred at the Fuego-Acatenango massif (figure 5). Tectonic earthquakes, torrential rains, or steam explosions can also trigger slope failures, which are commonly orders of magnitude smaller in volume than those triggered by magmatic intrusion. Debris avalanches can attain speeds in excess of $150 \mathrm{~km}$ per hour. Small-volume debris avalanches typically travel only a few kilometers from their source, but large-volume debris avalanches can travel tens of kilometers from a volcano. Debris avalanches destroy everything in their paths and can leave deposits of $10 \mathrm{~m}$ to more than $100 \mathrm{~m}$ thick on valley floors. 
Lahars, also called mudflows and debris flows, are masses of mud, rock, and water that look much like flowing concrete. They occur when water mobilizes large volumes of loose mud, rock, and volcanic debris. Commonly, landslides and avalanches will incorporate enough water to form lahars. Lahars, like floods, inundate floodplains and submerge structures in low-lying areas. They can travel many tens of kilometers down valley at speeds of tens of kilometers per hour. Lahars destroy or damage everything in their paths through burial or impact. They follow river valleys and leave deposits of muddy sand and gravel that can range to several meters or more thick. They are particularly hazardous because they travel farther from a volcano than any other hazardous phenomenon except tephra, and they affect stream valleys where human settlement is usually greatest. In some instances, lahars clog channels or block tributaries so that water collects behind the blockage. The impounded water can spill over the blockage, quickly cut a channel, catastrophically drain the water and generate floods that move down the valley. Breaching of such blockages may occur within hours or months after impoundment.

Like floods, lahars range greatly in size. The smallest lahars occur most frequently (perhaps every few years), whereas the largest occur on the order of centuries to millennia. The amount of water and loose volcanic debris determines lahar size. Eruptions can dump millions of cubic meters of sediment into channels that, when mixed with water during subsequent rains, causes lahars.

Landslides and lahars can cause problems long after the original eruptions. Once lahars fill stream channels with sediment, the streams begin to erode new paths, and the new stream channels can be highly unstable and shift rapidly as sediment is eroded and moved farther down valley. Also, because stream channels are clogged with sediment, they have less ability to convey water and thus are more susceptible to flooding by smaller-magnitude floods. Floods and lahars can persist for years to decades after eruptions.

\section{PAST EVENTS AT FUEGO AND ACATENANGO VOLCANOES}

Volcanism at the Fuego-Acatenango volcano complex has occurred intermittently for more than 230,000 years [2], and historical observations of eruptions date back nearly 500 years [1]. Fuego has erupted more than 60 times historically, but Acatenango has erupted only twice in the $20^{\text {th }}$ century. Most of the information about Acatenango's past behavior and some information about Fuego's behavior comes from studies of deposits produced by prehistoric events. Eruptive behavior has varied from vigorous explosions, accompanied by tephra falls and pyroclastic flows, to effusive lava flows (figure 5). At least two voluminous debris avalanches occurred in the last 80,000 years.

The volcano massif mostly grew in the past 84,000 years [1]. About 84,000 years ago the Los Chocoyos ash erupted from Lake Atitlán caldera. It comprises an underlying, tephra deposit (unit H) and an overlying ignimbrite. The unit is widespread and serves as a stratigraphic marker in the vicinity of Fuego and Acatenango [1]. After the Los Chocoyos ash fell eruptions of Acatenango Antiguo emplaced numerous lava flows [1]. Activity at Acatenango Antiguo culminated sometime before 43,000 years ago, with a huge debris avalanche that is now exposed near $\mathrm{La}$ Democracia (figure 7 , plate 1 ).

Between 43,000 years before present (BP) and about 5,000 years BP, Yepocapa cone grew at the site of Ancient Acatenango. Eruptions produced lava flows, pyroclastic flows, and numerous tephra-fall deposits (figure 5). The last known eruption from Yepocapa was about 5,000 BP, but Yepocapa should be considered potentially active.

Beginning by about 20,000 years ago, eruptions began from the Pico Mayor de Acatenango vent. Eruptions have produced widespread tephra layers, lava flows, and pyroclastic flows (figure 5) [1]. The last known pyroclastic flows erupted about 2,300 years BP. The last widespread tephra deposits erupted about 1,900 years BP. Historical accounts suggest an eruption of Acatenango in AD 1661. Phreatic eruptions occurred in AD 1924 to 1927 and in December 1972. 
Volcanism at the approximate location of Meseta volcano began 230,000 years ago [2]. Numerous lava flows were emplaced, but no known deposits of pyroclastic flows or tephras have been correlated to Meseta. One of the youngest lava flows is less than 30,000 years BP [2]. After emplacement of this lava, but before about 8,500 years BP, an enormous edifice collapse occurred at Meseta. The resulting debris avalanche deposit now underlies more than $300 \mathrm{~km}^{2}$ of the Pacific coastal plane south of Escuintla and has a volume of more than $9 \mathrm{~km}^{3}$ (figure 7, plate 1) [1]. A magmatic eruption probably accompanied the edifice collapse, but, if so, its deposits have not yet been detected. No subsequent volcanism is known at Meseta.

With an historical record of activity that includes more than 60 eruptions since AD 1524,
Fuego is one of the most active volcanoes in the world. These eruptions are typically short-lived (hours to a few days), violent vulcanian eruptions that commonly include pyroclastic flows. The historical record shows four 20-to-50-year-long clusters of activity and sporadic intermittent activity (figure 4). Widespread pyroclastic deposits east of Fuego with ${ }^{14} \mathrm{C}$ ages of $980 \pm 50 \mathrm{BP}, 1050$ $\pm 70 \mathrm{BP}$, two at about $1350 \mathrm{BP}(1330 \pm 60,1375 \pm$ $45)$, and $3530 \pm 70 \mathrm{BP}$ suggest that more voluminous eruptions, which fill barrancas and spread widely, sometimes occur. Extrapolating the historical volume rate of eruption suggests that the entire edifice of Fuego volcano could have been constructed in 8,500 years [1]. An age determination on one of the youngest Meseta lavas constrains the age of Fuego to be less than 30,000 years old.

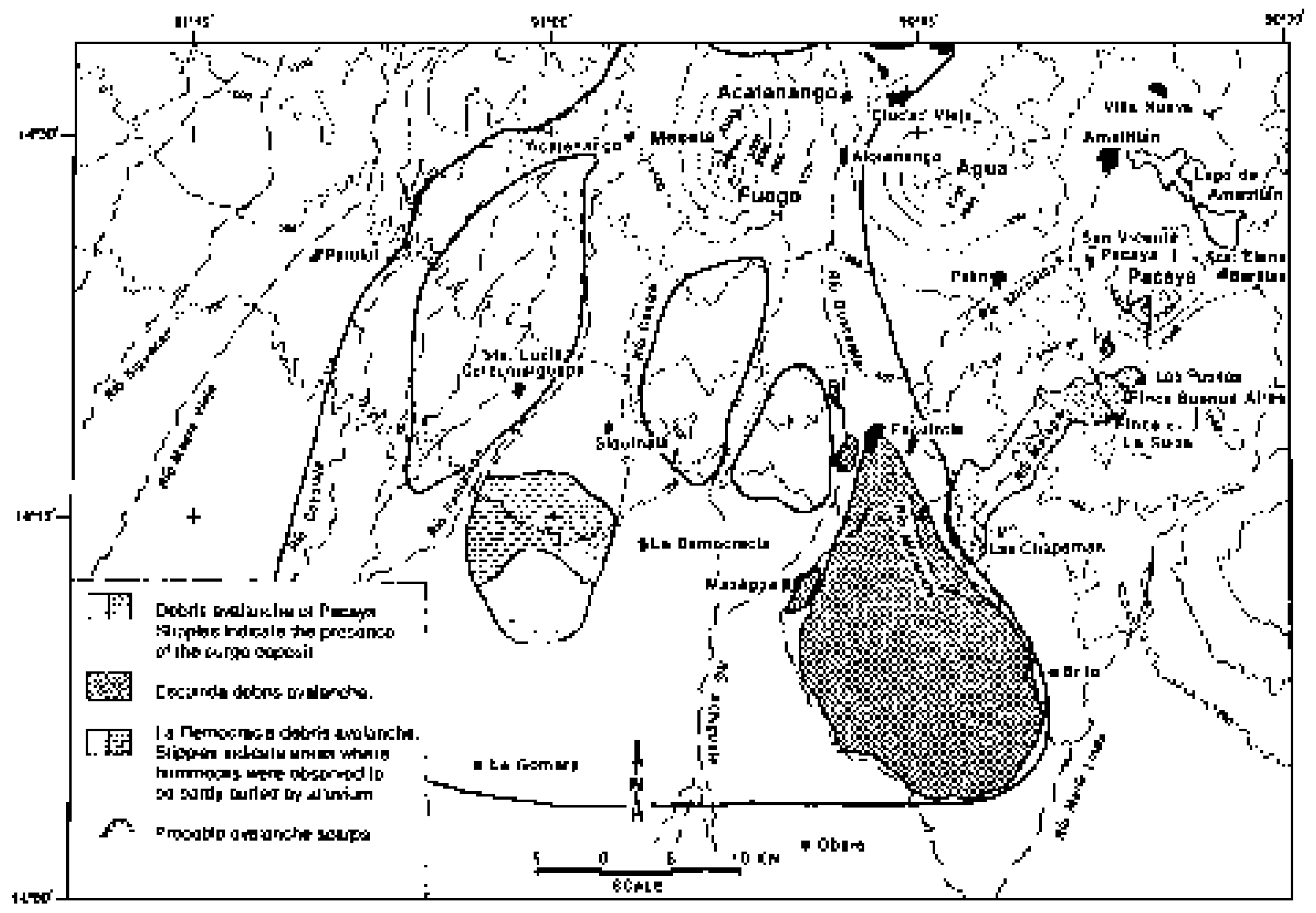

Figure 7. Topographic map showing distribution of debris-avalanche deposits from the Fuego-Acatenango volcano complex and hazards from future debris avalanches. Area encompassed within heavy dark line indicates areas that might potentially be at risk if debris avalanches should occur in the future (Modified from Vallance et al., 1995). 
The most recent eruption of Fuego occurred in May 1999, and the most recent large eruption occurred in 1974. The 1974 eruptions spread 20 $\mathrm{cm}$ or more ash more than $50 \mathrm{~km}$ to the southwest (figure 8) [1]. Both eruptions produced pyroclastic flows that moved up to $10 \mathrm{~km}$ down valleys and traveled $60 \mathrm{~km} / \mathrm{hr}$. Subsequent rains, especially during the summer monsoons, mobilized lahars that traveled up to $10 \mathrm{~km}$ beyond pyroclastic flow termini (as much as $20 \mathrm{~km}$ from the summit). A significant volume of loose volcaniclastic debris remains stored in steep upper reaches of the barrancas that head on Fuego.

Although there have been few historical eruptions at Acatenango, heavy rainfall, especially during the rainy season, could trigger landslides and debris flows on the steep slopes of the volcano during quiescent periods. In October 1998 at Casita volano in Nicaragua, torrential rain triggered an avalanche and debris flow that swept down the volcano, spread out on the apron of the volcano,

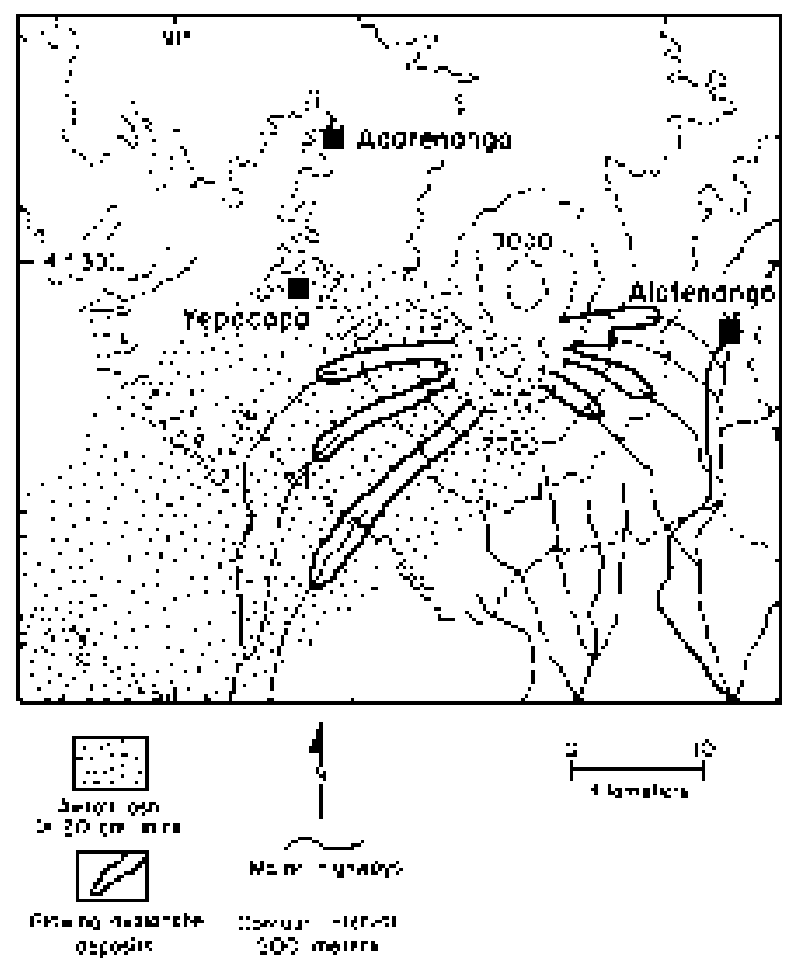

Figure 8. Topographic map showing distribution of pyroclastic flows (denoted glowing avalanches here) and tephra fall thicker than $20 \mathrm{~cm}$ from the 1974 eruption of Fuego volcano. (Adapted from Davies et al., 1978). destroyed two towns and killed more than 2,500 people. Steep dissected slopes, partly affected by hydrothermal alteration of the rocks, made Casita more susceptible to such an event than were younger more active volcanoes nearby. Acatenango volcano also has steep slopes and rocks that have been partly weakened by hydrothermal alteration. It is thus susceptible, in the event of torrential rain, to an avalanche and a debris flow much like that which occurred at Casita.

\section{POTENTIAL FUTURE ACTIVITY AT FUEGO VOLCANO}

On the basis of historical accounts, future volcanism of Fuego volcano will comprise moderate to strong eruptions that include pyroclastic flows which move up to $20 \mathrm{~km}$ from source and tephra falls which blow up to $100 \mathrm{~km}$ down wind. Less explosive eruptions will form lava flows. Shallow intrusion of magma or explosions could trigger an edifice collapse and debris avalanche. A huge debris avalanche could flow up to $50 \mathrm{~km}$ to the south and destroy everything in its path, but has a very low probability of occurring (about one chance in twenty thousand years). Lahars will probably derive from heavy rains on loose pyroclastic debris. Such lahars are most probable soon after eruptions and decrease in likelihood each year thereafter. Such lahars at Fuego could easily move 20 to $30 \mathrm{~km}$ from the volcano. Deposition of laharic debris is apt to choke channels with debris, increase the chance for overbank flooding during rainy seasons, and periodically cause channels to shift course. Floods and aggradation can damage infrastructure and inconvenience people in populated areas 20 to 40 $\mathrm{km}$ downstream of the volcano.

\section{POTENTIAL FUTURE ACTIVITY AT ACATENANGO VOLCANO}

Like Fuego, Acatenango and its satellite vent, Yepocapa, can erupt explosively to produce pyroclastic flows and widespread tephra falls, though the lack of historical volcanism of this type 
suggests that the probability of explosive eruptions at Acatenango is less than that at Fuego. Effusive volcanism is also possible at Acatenango. More likely are phreatic eruptions of limited extent. Such eruptions are apt to spread fine ash within $10 \mathrm{~km}$ of the summit and hurl ballistic bombs up to one kilometer or so. Landslides and debris flows are also possible during torrential rainstorms. Because there is less loose, easily erodible volcaniclastic material on the slopes of Acatenango than on Fuego, debris flows having this origin are less likely than at Fuego. Furthermore, these phenomena are apt to occur only during unusually intense rain.

\section{VOLCANO-HAZARD-ZONATION MAPS}

The accompanying volcano-hazard-zonation maps (plates 1,2,3, and 4) show areas that could be affected by future hazardous geologic events at or near Fuego and Acatenango volcanoes. Individual events typically affect only part of a hazard zone. The location and size of an affected area will depend on the location of the erupting vent or landslide, the volume of material involved, and the character of the eruption, especially its explosivity.

Potentially hazardous areas around Fuego and Acatenango volcanoes include proximal and distal lahar-hazard zones, pyroclastic-flow-and-lava-flow hazard zones, and tephra-fall hazard zones. Some zones are subdivided further on the basis of their relative degree of hazard. Hazard-zone boundaries derive from three main factors. First are the magnitudes of each type of event common at the volcano, as inferred from historical accounts and prehistoric deposits. Second, in the case of lahars, is an empirical model that calibrates laharinundation limits on the basis of lahars of known volume that occurred at other volcanoes. Finally, we apply our experience and judgment derived from past experience with events of a similar nature at other volcanoes.

Although sharp boundaries delineate each hazard zone, the limit of the hazard does not end abruptly at the boundaries. Rather, the hazard decreases gradually as distance from the volcano increases, and, for lahars, decreases rapidly with increasing elevation above valley floors. Areas immediately beyond distal hazard zones are not free of risk because the hazard limits can be located only approximately, especially in areas of low relief. Many uncertainties about the source, size, and mobility of future events preclude precise location of the boundaries of hazard zones.

Users of our hazard maps should be aware that we have not exhaustively simulated all potentially hazardous landslide and lahar areas. The edifice of the Fuego-Acatenango massif is steep, incised, and partly affected by hydrothermal weakening of the rock. For this report, we selected prominent channels directed toward populous areas in order to define the most significant impacts of inundation from lahars of various volumes. Other channels for which we have not modeled lahar inundation are not necessarily devoid of lahar hazard. Landslides and lahars from other unmapped channels could also threaten life and property.

\section{Proximal lahar- hazard zones}

The proximal lahar-hazard zone includes areas immediately surrounding Fuego and Acatenango volcanoes, and extends about 4 to $5 \mathrm{~km}$ outward from the summit depending upon local topography (plates 1 and 2) [2]. This zone delineates areas where lahars originate. During periods of volcanic unrest or during an eruption, this area should be evacuated because events can occur too quickly for humans to escape harm. Avalanches and lahars will originate in the proximal area, and deposits from small slides and flows may be restricted to this zone. However, large debris avalanches and lahars will travel away from the volcano and flow onto adjacent slopes. The extent of inundation from these larger lahars is the basis for defining distal lahar-hazard zones.

\section{Distal lahar-hazard zones}

An automated empirical technique calibrated with data from other volcanoes [3] estimates potential areas of inundation from lahars of various volumes. For each channel analyzed, we define four to five nested hazard zones that depict 
anticipated inundation by hypothetical "design" lahars having different volumes. The largest design lahar, reflects our estimate of the largest probable lahar generated on the steep slopes of Acatenango or Fuego volcanoes (plates 1 and 2) [3]. The intermediate and smallest design lahars are more typical lahar volumes for each volcano. Lahars of these sizes have occurred historically at Fuego and would be likely at Acatenango after an eruption or during severe rainstorms. The least voluminous lahars are those most likely to recur.

Large lahars are less likely to occur than small lahars. Thus, the nested lahar-hazard inundation zones show that the likelihood of lahar inundation decreases as distance from the volcano and elevation above the valley floors increases. No lahar as voluminous as 16 million cubic meters has occurred historically at Fuego volcano. Nonetheless, after large eruptive episodes like those of 1974 and 1932, lahars, floods, and aggradation owing to lahars upstream have affected areas as far downstream as the distal margins of the 16-million-cubic-meter zone (plate 1). The annual probability for inundation of the most distal area is about equal to the probability of larger eruptions, which occur every 30 to 50 years at Fuego. Smaller lahars are sure to occur for several years after each pyroclastic eruption.

Lahars at Acatenango are considerably less likely to occur than those at Fuego. Lahars of all designated sizes could form on the volcano's slopes if unusually intense rainstorms occur. The largest design lahar is based on the size of the largest lahar to occur during Hurricane Mitch (plate 2). On 30 October 1998, several days of intense rain derived from Hurricane Mitch, triggered a slope failure on the south side of Casita volcano, Nicaragua. The avalanche, in turn, generated a lahar of 2 to 4 million cubic meters that swept down the south side of the volcano, spread out on the aprons of the volcano, destroyed two towns, and killed about 2,500 people. The likelihood of an intense storm, like Hurricane Mitch, being focused at Acatenango is probably of the order of 1 in 100 years. Such a storm would not invariably trigger lahars as large as the one at Casita. Smaller lahars at Acatenango are more likely to occur, and may occasionally result from heavy rains that normally occur each year during the rainy season of May to November.

In general, lahar hazard zones extend 15 to $25 \mathrm{~km}$ from the summit crater, but a few extend farther (plates 1 and 2). Local topography plays a large role in controlling lahar distance travelled. Although lahars originate in and flow along steeply incised drainages on the flanks of the volcano, these channels shallow and the topography flattens along alluvial fans south of the volcanoes. As a result, lahars rapidly spill out of channels, spread, and stop. The most distant hazard zones coincide with the most deeply incised channels, in which lahars will remain confined. Despite their relatively short runout distances, even the smallest lahars can be devastating.

Drainages south of Fuego are so choked with volcaniclastic sediment from lahars and pyroclastic flows that channels occasionally fill with sediment and switch course. Until 1974, Río Tanilya followed the course of Río Obispo toward Siquinalá; afterward, it switched course and flowed southeastward into Río Panteleón. Areas likely to be affected by continuing sedimentation and channel shifting are designated in drainages south of Fuego volcano. These areas will only be affected when sedimentation causes an existing channel to shift. Hazards in these drainages are less than in neighboring channels that head on the volcano, but, as in neighboring drainages, decrease with distance downstream. Channels may change course suddenly, and when they do hazards in the new channel are greatly increased.

\section{Pyroclastic-flow and lava-flow hazard zones}

Pyroclastic flows (plate 3) have occurred during every major and most minor eruptions at Fuego. Such flows occur every 10 to 20 years, but can be more frequent. Pyroclastic flows are likely to move up to 10 or $12 \mathrm{~km}$ from their source at the summit. Fuego also produces lava flows. These can move 5 to $20 \mathrm{~km}$ from source (figure 8 , plate 3). Occasionally, parts of lava flows on the very steep slopes of Fuego will collapse to produce pyroclastic flows. During historical time, lava 
flows have been less common at Fuego than pyroclastic flows.

Acatenango most recently produced pyroclastic flows about 2000 years ago. On the basis of its past record, pyroclastic flows are likely at Acatenango about once every 1000 years. Like those at Fuego, pyroclastic flows at Acatenango are likely to move up to 10 or $12 \mathrm{~km}$ from their source at the summit (plate 4). Lava flows will also occur at Acatenango during eruptions and could move up to $10 \mathrm{~km}$ down slope (plate 4). Their likelihood is of the order of one in one thousand years.

\section{Tephra-fall hazard zones}

Tephra fall deposits from Fuego may occur up to $100 \mathrm{~km}$ downwind. On the basis of historical eruptions tephra deposits could be $5 \mathrm{~cm}$ thick or more within $50 \mathrm{~km}$ of source, $10 \mathrm{~cm}$ thick or more within $25 \mathrm{~km}$ of source, and $20 \mathrm{~cm}$ thick or more within $15 \mathrm{~km}$ or source (figure 9). Tephra can blow any direction, but will most probably blow east to east-southeast in the months from December though May and west to westsouthwest in the months from June to December (figure 10). Tephra falls of 10 to $20 \mathrm{~cm}$ or more can potentially cause roofs to collapse. Roof collapse is more likely if rains accompany tephra so that it is wet.

Numerous people live within areas that could be affected by tephra from Fuego (table 1). Tephra deposits of the size modelled in figure 9 are likely to occur about once every 20 to 50 years. Smaller tephra falls will occur more frequently. Tephra falls from Acatenango could be as large as those from Fuego, but are much less likely ( $\mathrm{ca}$ once per thousand years). The tephra distribution shown for Fuego (figure 9) is also applicable for Acatenango since the volcanoes are centered in nearly the same place.

\section{Debris-avalanche hazard zones}

Debris avalanches have occurred twice at the Fuego-Acatenango volcano complex in the past 80,000 years. The largest of these resulted from the edifice collapse of Meseta circa 10,000 years ago, flowed past the present site of Escuintla, and spread over more than $300 \mathrm{~km}^{2}$ of the Pacific coastal plain to a distance of up to $50 \mathrm{~km}$ from source (figure 7, plate 1). The older one apparently derived from an edifice collapse of Acatenango Antiguo very approximately about 40,000 years ago. It moved past the present site of La Democracia to a distance of more than $40 \mathrm{~km}$ from source.

Debris avalanches can occur at Fuego and Acatenango but should be considered as very remote possibilities, on the order of 1 in 20,000 years. Nonetheless, scientists should be aware of potential precursors of future possible debris avalanches. Such precursors might include bulging of the volcano edifice, formation of major arcuate fractures in the edifice, and signs of shallow intrusion of magma with the upper edifice. On the basis of past events at the Fuego-Acatenango volcano complex, debris avalanches could have height-to-runout ratios of as little as 0.07 and travel up to $50 \mathrm{~km}$ from source (figure 7). The debrisavalanche hazard zone, shown as a heavy dark line in figure 7, derives from the size and mobility of past debris avalanches at the volcano complex. A single debris avalanche would not cover the entire area denoted but could cover a significant fraction of that area.

\section{HAZARD FORECASTS AND WARNINGS}

Scientists can recognize and monitor indicators of impending volcanic eruptions. The movement of magma into a volcano prior to an eruption causes changes that can usually be detected by various geophysical instruments and visual observations. Swarms of small earthquakes are generated as rock fractures to make room for rising magma or as heating of fluids increases pressures underground. Heat from the magma can increase the temperature of ground water and raise temperatures and enhance steaming from fumaroles; it can also generate small steam explosions. The composition of gases emitted by fumaroles changes as magma nears the surface, 

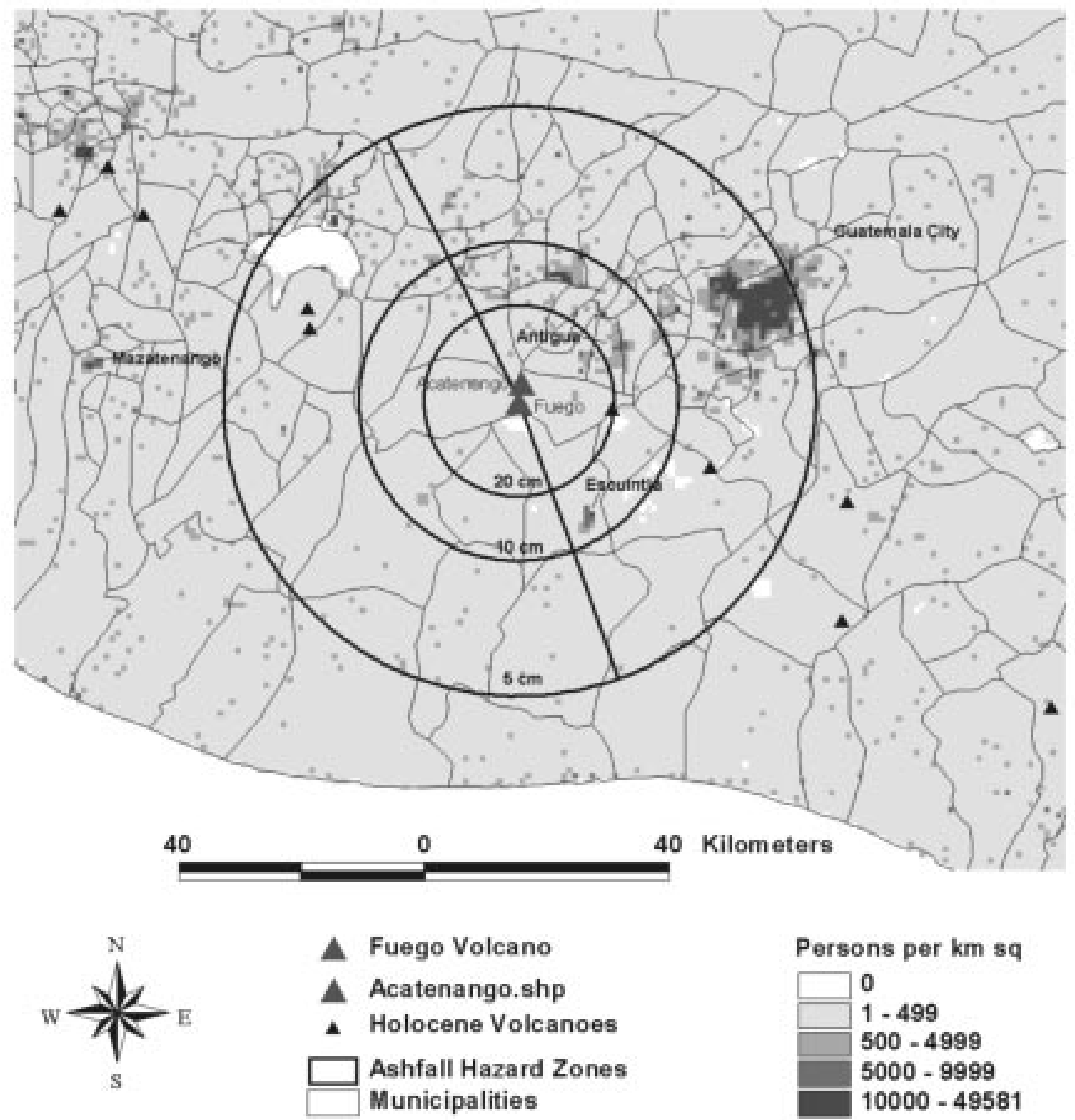

Figure 9. Map showing population density and tephra-fall hazard zones of $20 \mathrm{~cm}$ at $15 \mathrm{~km}$ distance, 10 $\mathrm{cm}$ at $25 \mathrm{~km}$ distance, and $5 \mathrm{~cm}$ at $50 \mathrm{~km}$ distance for the Fuego-Acatenango volcano complex. See text for discussion. 
Table 1. Population that could be affected by tephra falls like those of 1974 from Fuego.

\begin{tabular}{lccr}
\hline Quadrant & Radius & $\begin{array}{c}\text { Maximum } \\
\text { thickness }\end{array}$ & $\begin{array}{c}\text { Population that } \\
\text { could be affected }\end{array}$ \\
\hline Western & $15 \mathrm{~km}$ & $20 \mathrm{~cm}$ & 14,000 \\
Eastern & $15 \mathrm{~km}$ & $20 \mathrm{~cm}$ & 60,000 \\
Western & $25 \mathrm{~km}$ & $10 \mathrm{~cm}$ & 49,000 \\
Eastern & $25 \mathrm{~km}$ & $10 \mathrm{~cm}$ & 429,000 \\
Western & $40 \mathrm{~km}$ & $5 \mathrm{~cm}$ & 364,000 \\
Eastern & $40 \mathrm{~km}$ & $5 \mathrm{~cm}$ & $2,730,000$ \\
\hline
\end{tabular}

and injection of magma into the volcano can cause swelling or other types of surface deformation.

Guatemala has one seismometer near Fuego, and a modest regional seismic network, so a significant increase in volcanigenic earthquakes at Fuego volcano would be noticed quickly. There are not presently enough seismometers at Fuego to locate earthquakes, and it would be difficult to distinguish and locate new volcanic earthquakes that might be associated with Acatenango volcano.

Periods of unrest at volcanoes produce times of great uncertainty. During the past few decades

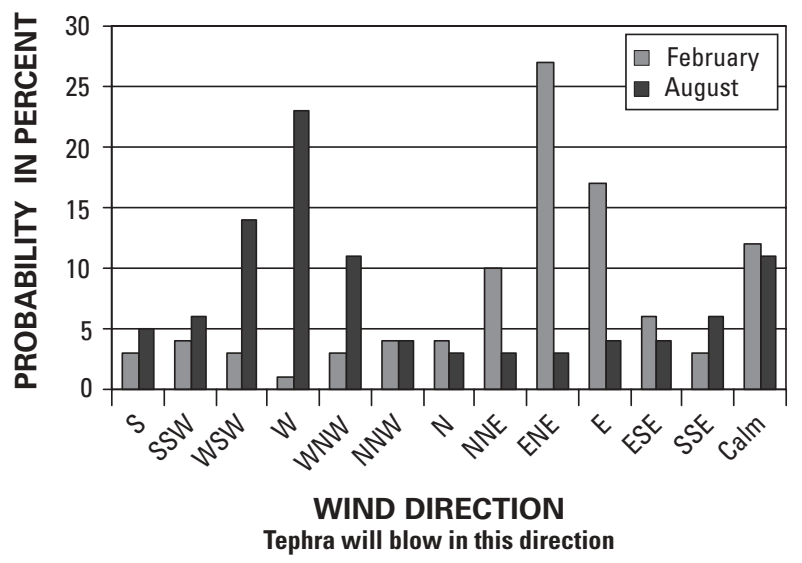

Figure 10. Map showing the probability of wind directions between 10,000 and 50,000 feet for Guatemala. February directions are typical of the dry season from December though May and August directions are typical of wind directions for the rainy season from June to December. Note that directions given here are the direction in which tephra plume will move rather than directions from which winds move. substantial advances have been made in volcano monitoring and eruption forecasting, but still scientists can often make only very general statements about the probability, type, and scale of an impending eruption. Precursory activity can go through accelerating and decelerating phases, and sometimes die out without an eruption. Government officials and the public must realize the limitations in forecasting eruptions and must be prepared to cope with such uncertainty.

Despite advances in volcano monitoring and eruption forecasting, it is still difficult, if not impossible, to predict the precise occurrence of landslides triggered by earthquakes or torrential rains. Therefore, potentially lethal lahars can, and most likely will, occur again at Fuego and Acatenango volcanoes without warning. Government officials and the public need to recognize the locations of lahar hazard zones and realize that the events depicted by these hazard zones can occur without warning.

\section{PROTECTING COMMUNITIES AND CITIZENS FROM VOLCANO-RELATED HAZARDS}

Communities, businesses, and citizens need to plan ahead to mitigate the effects of future volcanic eruptions, debris avalanches, and lahars from Fuego and Acatenango volcanoes. Longterm mitigation efforts must include using information about volcano hazards when making decisions about land use and siting of critical 
facilities. Future development should avoid areas judged to have an unacceptably high risk or be planned and designed to reduce the level of risk.

When volcanoes erupt or threaten to erupt, a well-coordinated emergency response is needed. Such a response will be most effective if citizens and public officials have a basic understanding of volcano hazards and have planned the actions needed to protect communities.

Because a volcanic eruption can occur within weeks to months after the first precursory activity and because some hazardous events, such as landslides and lahars, can occur without warning, suitable emergency plans should be made in advance. Because Fuego is continuously active at some level, public officials need to consider issues such as public education, communications, and evacuations as part of a response plan.

Emergency plans already developed for floods may apply to some extent, but may need modifications for hazards from lahars. For inhabitants in lowlying areas, a map showing the shortest route to high ground will also be helpful for evacuations.

Knowledge and advance planning are the most important items for dealing with volcano hazards. Especially important is a plan of action based on the knowledge of relatively safe areas around homes, schools, and workplaces. Lahars pose the biggest threat to people living or recreating along channels that drain Fuego and Acatenango volcanoes. The best strategy for avoiding a lahar is to move to the highest possible ground. A safe height above river channels depends on many factors including the size of the lahar, distance from the volcano, and shape of the valley.

\section{REFERENCES}

Basset, T., 1996, Histoire éruptive et évaluations des aléas du volcan Acatenango Guatemala: $\mathrm{PhD}$ thesis, University of Geneva, $240 \mathrm{p}$.

Bonis, S.B. and Salazar, O, 1973, The 1971 and 1973 eruptions of Volcán de Fuego, Guatemala, and some socio_ecoonomic considerations for the volcanologist: Bulletin of Volcanology, v. 37, p. 394-400.

Chesner, C.A. and Halsor, S.P, 1997, Geochemical trends of sequential laval flows from Meseta volcano, Guatemala: Journal of Volcanology and Geothermal Research, v. 21, p. 25-41.

Chesner, C.A. and Rose. W.I., 1984, Geochemistry and evolution of Fuego volcano complex, Guatemala: Journal of Volcanology and Geothermal Research, v. 78, p. 221-237.

Davies, D.K., Querry, M.W. and Bonis, S.B., 1978, Glowing avalanches from the 1974 eruption of the volcano Fuego, Guatemala: Geological Society of America Bulletin, v.89, p. 369-384.

Iverson, R.M., Schilling, S.P., and Vallance, J.W., 1998, Objective delineation of lahar-hazard zones downstream from volcanoes: Geological Society of America Bulletin, v. 110, p. 972-984.

Muñoz, C., 2001, Analyse et simulation des instabilités de terrain et lahars sur les volcans Acatenango-Fuego, zonage par système d'information géographique: $\mathrm{PhD}$ thesis, University of Geneva, 229 p.

Rose, W.I., Anderson, A.T., Woodruff, L.G., and Bonis, S.B., 1978, The October 1974 basaltic tephra from Fuego volcano: description and history of the magma body: Journal of Volcanology and Geothermal Research, v. 4, p. 3-53.

Rose, W.I., Mercado, R., Matías, O. and Girón, J., 1987, Volcanic hazards of Fuego volcano, Guatemala, Preliminary Report: Michigan Technological University, U.S. Geological Survey, and INSIVUMEH, $30 \mathrm{p}$.

Vallance, J. W., Siebert, L., Rose, W. I., Girón, J, and Banks, N. G., 1995, Edifice collapse and related hazards in Guatemala: J. Volcanol. and Geotherm. Res., v. 66, p. 337-355.

Vessel, R.K. and Davies, D.K., 1981, Nonmarine sedimentation in an active fore ark basin, SEPM Special Publication no. 31, p. 31-45. 


\section{Additional Suggested Reading}

Blong, R.J., 1984, Volcanic hazards: Academic Press, Orlando, 424 p.

Tilling, R.I., ed., 1989, Volcanic hazards: Short course in geology, v. 1, American Geophysical Union, Washington, D.C., 123 p.

Vallance, J.W. 2000, Lahars: in Sigurdsson, H., Houghton, B., McNutt, S., Rymer, H., and Stix, J., Encyclopedia of Volcanoes, Academic Press, San Diego, p. 601-616.

\section{END NOTES}

[1] For Acatenango volcano, the geologic data upon which this report is based come chiefly from Basset (1996); for Fuego, geology derives from Bonis and Salazar (1973), Rose et al. (1978), Davies et al. (1978), Vessel and Davies (1981), Vallance et al. (1995), and Muños (2001).

[2] $\mathrm{An}{ }^{40} \mathrm{Ar} /{ }^{39} \mathrm{Ar}$ age performed by Marvin Lanphere of the U.S. Geological Survey Geochronology Laboratory shows that one of the oldest lavas exposed in the slopes of Meseta (FL-2, Chesner and Halsor, 1997) is $234,000 \pm 31,000$ years old. Lanphere also determined that one of the youngest lava flows (FL-27, Chesner and Halsor, 1997) has an ${ }^{40} \mathrm{Ar} /$ ${ }^{39} \mathrm{Ar}$ age of $18,000 \pm 11,000$.
[3] The maximum extent of the proximal laharhazard zone derives from the formula $\mathrm{H} / \mathrm{L}$ $\approx 0.5$, in which $\mathrm{H}$ is the elevation difference between the summits of Fuego and Acatenango and the hazard boundary line and $\mathrm{L}$ is the horizontal distance from the center of the summit crater to the hazard boundary line (see, for example, Iverson et al., 1998). The steep slopes within the proximal zone are the likely source of future lahars. More gentle slopes outside the proximal zone are areas where lahars will funnel into valleys, travel downstream, and spread out on alluvial fans.

[4] We constructed lahar-hazard zones by chosing design-lahar volumes of 500,000; 1,000,000; $2,000,000 ; 4,000,000$, cubic meters for Acatenango and 1,000,000; 2,000,000; 4,000,000, 8,000,000; and 16,000,000 cubic meters for Fuego. We then modelled each volume using a repeatable empirical model and digital cartographic technique described in Iverson et al. (1998). The model requires the choice of a reasonable range of volumes for each volcano. It then uses these volumes to compute average cross-sectional areas and areas of inundation for each lahar volume. The GIS based computer program, LAHARZ (Iverson et al., 1998) then calculates the extent of inundation downstream from source area in each drainage that heads on the volcano. 


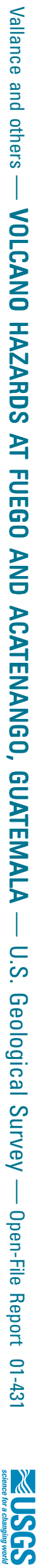

83 Printed on recycled paper 